Article

\title{
Design of a Spatial Data Model for the Sustainability of Population Sheltering Processes in the Czech Republic
}

\author{
Jakub Rak, Pavel Tomášek *(i) and Petr Svoboda \\ Department of Population Protection, Faculty of Logistics and Crisis Management, Tomas Bata University in Zlín, \\ nám. T. G. Masaryka 5555, 76001 Zlín, Czech Republic; jrak@utb.cz (J.R.); psvoboda@utb.cz (P.S.) \\ * Correspondence: tomasek@utb.cz
}

Citation: Rak, J.; Tomášek, P.; Svoboda, P. Design of a Spatial Data Model for the Sustainability of Population Sheltering Processes in the Czech Republic. Sustainability 2021, 13, 13503. https://doi.org/ $10.3390 /$ su132413503

Academic Editors: Genserik Reniers and Ming Yang

Received: 30 August 2021

Accepted: 24 November 2021

Published: 7 December 2021

Publisher's Note: MDPI stays neutral with regard to jurisdictional claims in published maps and institutional affiliations.

Copyright: (c) 2021 by the authors. Licensee MDPI, Basel, Switzerland. This article is an open access article distributed under the terms and conditions of the Creative Commons Attribution (CC BY) license (https:/ / creativecommons.org/licenses/by/ $4.0 /)$.

\begin{abstract}
This article is focused on the creation of a data model of an information system to support the processes of population sheltering $(\mathrm{PoS})$. PoS processes have undergone significant changes in the Czech Republic. The PoS system was transformed for the use of improvised shelters. For sustainable PoS, it is necessary to standardize the approach of crisis management staff. Key research hypotheses: the data model must respect the methodological framework of planning and implementation of the PoS, especially when used for the design and implementation of the improvised shelters; the standardization of residential buildings can be used to facilitate and streamline the sustainable process of planning of the PoS; the unified data model of the PoS can be considered suitable for standardization and development in the field of sustainable planning and implementation of the PoS. Softwares such as SW QGIS desktop 2.6.0, OpenStreetMap (OSM) spatial database, ESRI shapefile format, and S-JTSK/Krovak East North 5514 coordinate system were used for the verification of the spatial data model, and ASP.NET MVC 4.7.2 Microsoft SQL Server Express 2019, jQuery 3.3.1, Bootstrap 3.4.1, Kendo UI 2019.1.220, and virtual Windows Server 2016 were used for the implementation of the physical data model. The physical data model substantiates the benefits.
\end{abstract}

Keywords: modelling; sustainability; emergency management; civil protection processes; data model; spatial database

\section{Introduction}

Population sheltering (PoS) can be perceived from several standpoints [1,2]. The first "classic" standpoint is given by historical developments in the territory of the Czech Republic (CR). The glossary for population sheltering, environmental security, and national defense prepared by the Ministry of the Interior of the CR states the following [3]:

"The PoS is the use of shelters and other suitable premises in order to protect population against effects of luminous and heat radiation, penetrating radiation, contamination by radioactive dust, chemical or biological substances and against blast effects of weapons of mass destruction. For these purposes, the improvised and permanent shelters are used."

The General Directorate of the Fire Rescue Service of the CR defines the population sheltering in its glossary within the context of Executive Regulation No. 380/2002 as follows [4]:

"During emergency events the PoS is carried out by means of improvised and permanent shelters. The methods and extent of the collective PoS are specified in a sheltering plan, which is a part of the emergency plan for the region.

The improvised shelters (IS) are designed in accordance with the sheltering plan within reachable distances necessary for providing the PoS if permanent shelters are not available. 
Permanent shelters (PeS) are used for the PoS and include permanent protective areas in the basement of buildings or detached buildings."

Authors of professional literature define the PoS in a similar way to the glossary of the Ministry of the Interior of the CR. For instance, the publication "Emergency management and sheltering of the population during emergency events" by Hladký [5] can serve as an illustrative example. In addition, the professional publication "Collective protection of the population" by Pacinda and Pivovarník defines sheltering as "measures of protection against effects and consequences of large operational accidents and against effects of weapons of mass destruction. The PoS can be provided in the designated areas of underground or aboveground parts of buildings or other suitable premises self-converted by the population into IS while using materials from local sources, or in the PeS and protection systems of underground transportation constructions" [2].

The PeS are also used for emergency accommodation and civilian activities held in peacetime when there is a low risk of most threats [2]. The premises of the PeS are also used in a similar way in which other countries use them, for example, for parking, entertainment, or other purposes. This is the so-called dual-purpose usage of the PeS [2,6].

Based on these findings, sheltering can be understood in a broader context than it has been commonly known in the CR until recently. The change in the perception of the PoS is also supported by a new Concept of the protection of population (PP), namely by its explicitness and absence of specific descriptions of individual solutions within the PP [7].

Nowadays, there is only a small number of PeS available and the IS are planned on a theoretical level $[8,9]$. Real-life practice in the field of PoS is regulated by valid legislation, which expects the PeS to be gradually removed and replaced by the IS [7]. There have been changes in developments of security threats; their occurrences have decreased and were therefore side-lined. The IS are still relied on; however, the actual shelters are not being designed and suitable premises are not being sought [9].

The current situation is caused by many factors. Predominantly, the main factors include a low priority for the PoS and the absence of system support for designing and planning of the IS [8-10]. The current system in the CR is based on a set of elements used for the PS. Its main parts are as follows [2]:

- Municipalities which are obliged to provide sheltering on their territories;

- $\quad$ Fire Rescue Service (FRS) of the region which keeps records of shelters and removes the PeS from the records in accordance with valid legislative processes;

- The population, as an integral part of the PoS system, which is expected to be directly involved in the system;

- $\quad$ PeS and IS as the main tools, however, the IS can still be characterized by their insufficient planning and preparation [2].

The crucial positions in the system occupy the municipality, especially the mayor, and also improvised and permanent shelters. In particular, the absence of a system to support the designing and planning of the IS is evident in the municipalities [9]. The CR lacks a unified methodological tool, which would help the municipalities and their staff with the planning and implementation of the PoS. The inconsistency of approaches to the PS, and designing and planning of the IS are the basic problems. In the past, detailed plans and methodologies for designing and implementation of the IS were used. However, these plans and methodologies were cancelled without any substitution, namely because of the low priority placed on the $\operatorname{PoS}[8,10,11]$.

In order to solve this problem, it is necessary to create a unified methodology for the design and implementation of the IS and keeping a record of the PeS. Such a methodology would allow the establishing of a system in the individual municipalities and it would also provide a supportive tool for the state.

Nevertheless, the form of such a methodology remains problematic. The current trends in information support (InS) of the PP consider using various kinds of software. This is demonstrated by the massive use of SW solutions (tools) in the field of the PP and 
related fields, especially in emergency management (EM) [9]. This trend is evident not only in the Czech Republic but also in other countries [9].

In the field of the PoS, specific tools are not used; however, support is provided by tools used for the InS from other related fields, e.g., EM and PP. Even in these fields, there is not one unified tool that would be used in the whole CR; the choice of individual tools is dependent on user preferences (in this case municipalities) [9]. Owing to this fact, a number of information systems are used in the CR together with other single-purpose SW tools which are used, e.g., for modelling of emergency events, etc. [12]. The most frequently used tools include, for instance, Terex, Obnova, EMOFF, GINA, ARGIS, and various forms of web applications and protected access websites [13]. The last method is the most frequently used and it includes, for example, the access to emergency and contingency plans of regions, a survey of forces and resources, etc. [14]. From the perspective of PoS, these tools are not often used as information support. The tools for accessing the emergency and contingency plans of regions and some GIS applications used by individual municipalities are the only exceptions. This is where the "separate layers" focused on the PoS are created. Layers are used to display locations of the PeS or premises suitable for the IS. Applications that use the GIS are also widespread in the fields of evacuation, warning, and notification. Generally speaking, the PoS is rather underestimated on the part of municipalities and in most cases, it is not addressed at all [15].

Due to this fact, the InS tools of the PoS are not used as much as necessary. One of the exceptions is the municipal authority of the town of Most where the web GIS application is used as the InS tool [16].

In addition, this web application serves the needs of the public, especially for informing them about the possibilities of the PS. In order to create the given layer, the data model for digital processing of monitored phenomena of territorial analytical data in the GIS [17] was used. This data model represents a unified approach and includes a section dedicated to the PS. However, it only deals with the location and capacity of the PeS and premises suitable for the IS [16] and therefore, it lacks the important information on the planning and implementation of the PS. Nowadays, the said model is used only in five regions out of 14. Apart from the town of Most, the GIS application is also used as the InS in the town of Pilsen. In addition, the Department of Emergency Management of the town of Pardubice uses a desktop variant ArcGIS, version ArcView. They use it for administration and keeping a record of the PeS and premises for the IS [10]. Naturally, the previously mentioned examples of using the GIS application as the InS tools for the PoS are not the only ones in the CR. Personal consultations revealed several major problems associated with the use of the GIS as an InS tool for the PS. In particular, this applies to data [9], or more precisely, the "thematic data" describing the PoS. This data includes, for instance, capacities of shelters, conditions of shelters, materials needed for construction adjustments, shelter equipment, purpose of using shelters, and others.

The main issues associated with the PoS in the CR are the absence of a unified methodological tool for planning and implementation of the PoS and the absence of "thematic data" [18]. Based on these facts, it is necessary to create a unified data model for the PoS in order to standardize and support the planning and implementation of the PS. The data model will unify the approach of individual municipalities and it will provide support of SW tools for these activities. The data model must respect the methodological framework of the planning and implementation of the PoS, especially when used for the design and implementation of the IS [19]. This hypothesis is the core of this article. Therefore, the objective of the article is to contribute towards solving the problems of the PoS in the CR and to enhance the concept. The possible method of doing so is the creation of a methodology for designing and planning the IS and keeping a record of the PeS. This methodology is to be subsequently implemented into a data model processed in a spatial form. Finally, the presented solution is verified in laboratory conditions and tested in real-life conditions in the town of Uherské Hradiště. 
The number of resources is limited from the point of view of the spatial data model of PoS. However, there are specific applications, especially [15-17], which are relatively inconsistent, and the level of abstraction varies. The unification of PoS processes is a basic prerequisite for creating information support for a sustainable PoS system, as evidenced by $[9,13,20]$. The construction of the data model is based on basic constructs-entities [19] and the description of their properties-attributes. Entities represent objects in the real world, while attributes determine the properties of these objects $[18,19]$. Within data models, the level of abstraction is subjective and the analysis of legislative documents and existing standards can be used to define entities and their attributes [19]. Vector models clearly prevail over raster [21] from the point of view of the form of representation of spatial data models. Therefore, it is necessary to assign the spatial attributes of the respective entities [21] here. The basic principle of spatial data modeling is in accordance with the principles of data modeling. Three types of data models can be presented, namely, it is the conceptual data model representing the highest degree of abstraction. The second type is a logical data model and the last type is a physical data model, which is a form of data structure [22]. The correct design of the data model respects the following: data update, flexibility and extensibility of the model, position accuracy, compatibility with other data sources, and accessibility [22].

The aim of this article is to create a data model of the application to support the processes of PoS planning and preparation. The proposed data model is based on the unified methodology for designing and keeping a record of IS and PeS. The main hypothesis is the following: the data model must respect the methodological framework for planning and implementation of PoS, especially when used for the design and implementation of IS.

\section{Materials and Methods}

The basic materials and methods described in this chapter were used in the research. It is mainly a data modeling method based on the use of E-R diagrams and abstraction using a conceptual data model [19]. The information from "the unified methodology for designing and keeping a record of IS and PeS" was used to define the basic attributes [9].

The main hypothesis of the research presented in the introduction implies the need to respect the methodological framework of planning and preparation of PoS. The sustainability of PoS processes is evidenced by attempts to apply spatial data models in PoS [15-17].

It is possible to identify a non-uniform approach and different levels of detail of the attributes of the resulting models within each application. The dependence of the sustainability of PoS processes can be compared by analogy with the sustainability of processes from related areas of PP, e.g., for evacuation processes [6], individual protection [10], and others [20].

The following subchapters describe the process of creating a data model, the choice of locality for its testing together with the hypothesis of space typing for IS, and last but not least, "the unique methodology for designing and keeping a record of IS and PeS". The methodology is supplemented by a description of the determination of key attributes, such as the proctor protection factor for IS, capacity, etc. Within the construction of the physical data model, this chapter also describes the SW tools used.

\subsection{Data Model}

The design of a spatial data model is based on "the unified methodology for designing and keeping a record of IS and PeS" [9]. The implementation of the methodology is based on analysis and synthesis of available scientific documents together with the induction and deduction of the obtained data. These documents deal with problems of the PoS, and, these are the sources $[1,2,8,10,11]$. On the basis of these materials, the key entities and attributes that formed the final methodology were acquired. For this task, a comparison method was used. The methodology was created in MS Excel in xlsx format. This format was chosen because of its widespread use among the staff of the EM and PP. Owing to the selected format, the methodology can be used by the vast majority of departments which focus on 
the PP and PoS. To process graphical outputs incorporated in the methodology, the SW application FreeCAD v. 0.16 in 64-bit architecture was used. By means of this, SW plans for specific objects were processed. The methodology is based on previous activities of the authors and it is described in detail, e.g., in [9]. A part of the methodology is shown in Figure 1.

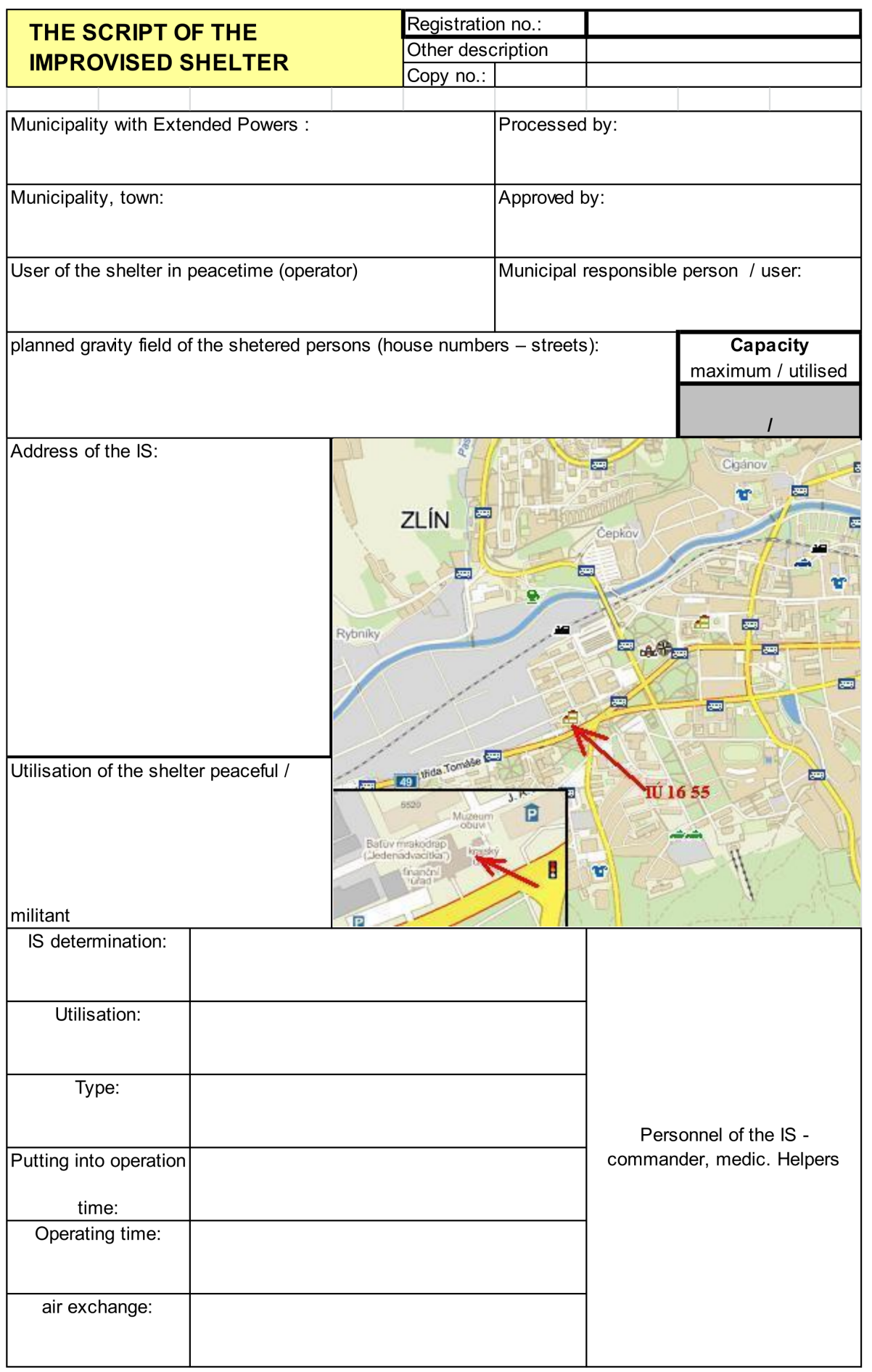

Figure 1. The unified methodology for designing and keeping a record of IS and PeS [9].

The value of the attribute "protection coefficient of the building" was based on calculations of protective properties of individual buildings (objects for the IS). 
Protective properties of buildings against penetrating radiation are defined by the so-called protective coefficient of the building $K_{0}$ (the protective coefficient of the shelterPCS). This coefficient indicates how many times the dose of radioactive radiation $D_{u}$ in the shelter is lower than the radioactive radiation dose $D_{0}$ at a height of $1 \mathrm{~m}$ above the exposed terrain around the shelter (see Equation (1)) $[9,11,23,24]$.

$$
\begin{gathered}
K_{0}=\frac{D_{0}}{D_{u}} \\
K_{0}=\frac{3.25 \times K_{s t}}{\left(1-V_{2}\right) \times\left(K_{z} \times K_{s t}+1\right) \times K_{m}} \\
K_{0}=\frac{0.65 \times K_{1} \times K_{s t}}{\left(1-V_{2}\right) \times\left(K_{z} \times K_{s t}+1\right) \times K_{m}} \\
K_{0}=\frac{0.77 \times K_{1} \times K_{s t} \times K_{p}}{\left(1-V_{2}\right) \times\left(K_{z} \times K_{s t}+1\right) \times\left(K_{p}+1\right) \times K_{m}} \\
K_{0}=\frac{0.77 \times K_{p r}}{V_{2}+K_{v c h} \times K_{p r}}
\end{gathered}
$$

Equations (2)-(5) serve to calculate the PCS for individual types of shelters. The following equation describes the calculation for shelters located in the middle section of multi-storied buildings.

The third equation is used to calculate the PCS for shelters, which are partially underground or those above ground level.

Equation (4) describes the calculation of PCS for the underground shelters with an extension.

The last equation is used to calculate the PCS of the completely underground shelters without extensions $[9,11,23,24]$.

Variables in individual equations are as follows:

K-PCS;

$K_{1}-$ coefficient of the effect of external walls;

$K_{s t}$-coefficient of reduction in radiation by the external wall;

$V_{2}$-coefficient of the width of the building;

$K_{z}$-coefficient of penetration of the radiation through openings;

$K_{m}$-coefficient of the influence of surrounding buildings;

$K_{p r}$-coefficient of the influence of ceiling structures;

$K_{p}$-coefficient of the influence of ceiling structures (for shelters with extensions);

$K_{v c h}$-coefficient of penetration of the radiation through the entrance.

In order to define the PCS $K_{0}$ and individual coefficients, it is necessary to know information on the construction.

- Surface density of walls and constructions.

The surface density is determined based on the tables [21]; the materials of the shelter must be known. The surface density is calculated by Equation (6).

$$
\rho=H \times X\left[\mathrm{~kg} / \mathrm{m}^{2}\right]
$$

where:

$\rho$-surface density of the brickwork;

$\mathrm{H}$-weight of $1 \mathrm{~m} 3$ of the construction;

$X$-thickness of the structure. 


\section{- $\quad$ Surface of openings.}

The total surface of the openings affects the protective properties of the selected premises. In addition, it determines the number of materials needed for adjustments. The surface of openings affects mainly the coefficient $K_{z}$ and the coefficient $K_{v c h}$ to a lesser extent.

- Room dimensions.

- Depth of sinking of the shelter and its location.

Generally, the depth of sinking of the shelter determines the choice of the basic equation for calculation of protective characteristics of the building.

- Information about the building and the surrounding built-up area.

This affects the parameters $K_{p}, K_{p r}, K_{1}$, and $K_{s t}$. These parameters are taken from the tables based on measurements [25].

The resulting protective properties are influenced by other factors as well, but they are rather insignificant.

Also, the attribute "capacity" was determined by calculation, which was based on the floor space. The capacity is $1-3 \mathrm{~m}^{2}$ per sheltered person in premises with filtered ventilation equipment (FVE) and $3-5 \mathrm{~m}^{2}$ in the premises without the FVE or forced ventilation. The total capacity of the IS must therefore comply with these requirements [10]. In other words, the maximum and minimum capacities are calculated for buildings with and without the FVE.

Individual entities and attributes of the data model are based on "the unified methodology for designing and keeping a record of IS and PeS". The crucial method in this part of the research was the modelling, or more precisely, the data modelling method. For the creation of the data model of the PoS on a conceptual level, the E-R diagram constructs were used [19]. The conceptual data model was implemented in the web interface Draw available at: https: / /www.draw.io / (accessed on 12 October 2021). The data model was designed as a spatial data model. For implementation of the logical data model, MS Excel was chosen because of its tabular layout. The physical data model was processed using the application Quantum GIS, QGIS Desktop 2.6.0, QGIS Browser 2.6.0. Additionally, physical structures and attributes were created. First, the file system of empty layers was created in the format ESRI shapefile with a '.shp' extension. A vector data model was chosen. Subsequently, the structure was slightly modified so that individual attributes could be implemented and most importantly, the type of geometry-the point was identified. The point as the type of geometry was used for structures of civil protection and the PeS and IS.

The ESRI shapefile format was chosen due to its easy transferability among individual GIS applications, and because it is widely used. It is fully compatible with the ArcGIS tools commonly used by municipal authorities.

For the same reason, the coordinate reference system obligatory for self-governing units was also adopted pursuant to Government Regulation No. 430/2006 Coll [26]. It is the coordinate system of the Uniform Trigonometric Cadastral Network (hereinafter S-JTSK). Two systems are supported as per the EPSG (Geodetic Parameter Set) and they are represented by names and codes S-JTSK (Ferro)/Krovak East North 5221 and SJTSK/Krovak East North 5514. Both systems use "mathematical" axis orientation. The system S-JTSK/Krovak East North 5514 was used to implement the data model. QGIS applications were used for the actual processing the spatial data model.

The spatial database OpenStreetMap (OSM) was used for the final implementation of the data model. Thematic data was created in the QGIS Desktop 2.6.0 interface.

Upon verifying the functionality of the spatial aspects of the data model, the creation of a physical data model followed as the last step of the process. For the implementation of the physical data model, the development environment ASP.NET MVC 4.7.2 was used together with the following technologies: Microsoft SQL Server Express 2019, jQuery 3.3.1, Bootstrap 3.4.1, and Kendo UI 2019.1.220. A thin client was chosen for the physical model, which was put on a virtual Windows Server 2016. The physical model can be accessed 
through a web interface by means of user accounts (domain www.uo.flkr.utb.cz (accessed on 12 October 2021)).

\subsection{Locality}

The town of Uherské Hradiště was chosen as the location for testing the data model as the information support tool for the PoS. Uherské Hradiště is a town with a population of 25,246 inhabitants, and it is located in the eastern part of the CR in the Zlín Region. It is a district town with a rich history and a developed industry. Based on methods of observation and analysis, the constraints for the implementation of the case study were specified.

One of the main constraints is the type of the object (building) intended for the IS. For the purposes of testing, the objects owned by the town were chosen due to their accessibility for physical observation. Objects owned by the town were further divided into residential buildings and other buildings (gyms, schools, etc.). Based on the detailed analysis, the method of the "standardization of objects for the IS" was applied. This method is based on the consistent design of several objects (residential buildings). On this basis, the objects are classified and included into one series. Based on the design consistency of the given series, the data related to the construction, equipment, and design of the IS can then be used for other objects of the same series without the need for adjustments. This is a general method devised by the authors in order to facilitate planning of the PoS [25]. Due to the unification of housing development in the last century, this method can be widely used in the $C R$, and it allows a considerable reduction in time necessary to obtain data for the given data models. Nevertheless, the weak point of this method is the fact that it can only be used in larger towns (over 20,000 inhabitants) because of the lack of the unification of construction of residential buildings in smaller towns. Therefore, the type of buildings in the territory of Uherské Hradište makes this location perfect for the use of the previously mentioned method.

Individual series of buildings were defined in housing estates called "Východ" (red windowpane), "Štěpnice" (orange windowpane), "Pod Svahy" (blue windowpane), "Malinovského" (yellow windowpane), and "Jarošov" (violet windowpane), while other buildings were defined near the streets "Stará Tenice"; (green windowpane) and "Na Rybníku" (brown windowpane). Locations of individual buildings are depicted in Figure 2 by means of color-coded windowpanes.

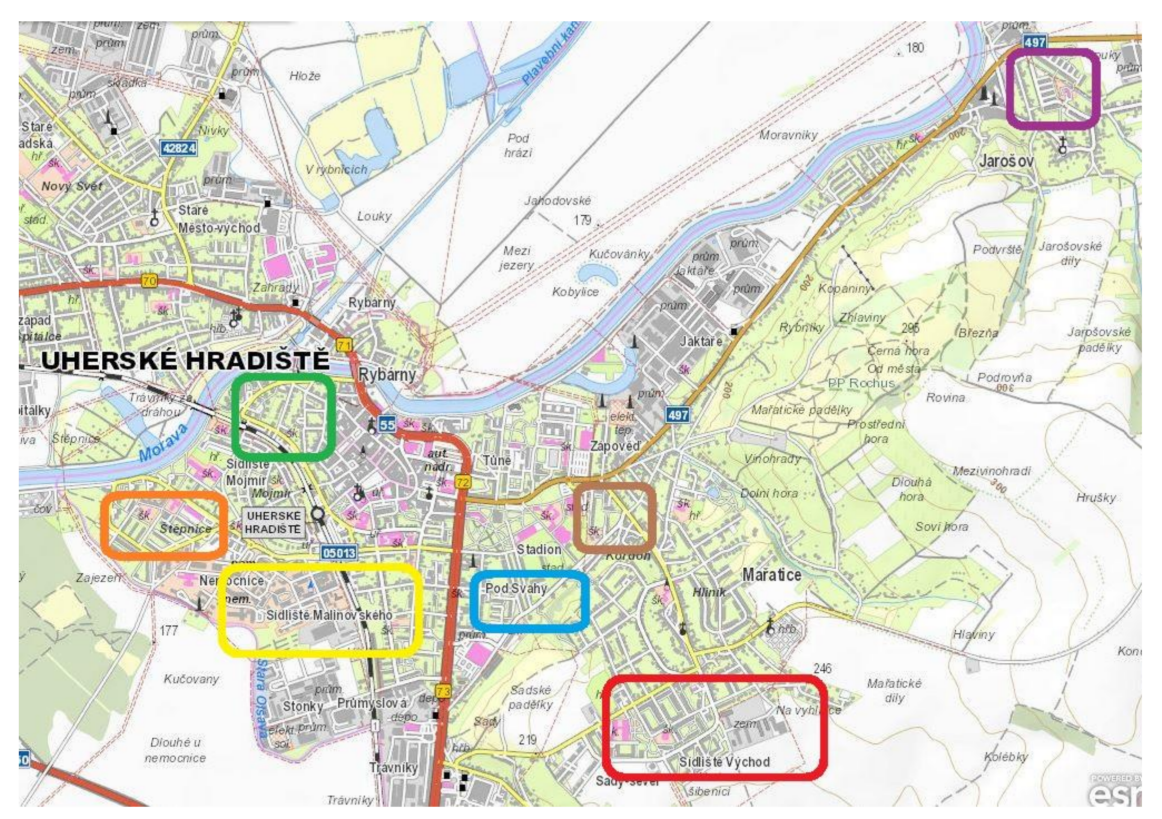

Figure 2. The individual series of buildings in the town of Uherské Hradiště $[27,28]$. 
Within the analyzed buildings, three basic series were defined, namely: OP 1.11., OP 1.31 , and G 32 [12,27]. These series of buildings of concrete construction are intended for residential use. Furthermore, a series of unspecified buildings was defined. It is impossible to identify the series type of these buildings because the buildings comprise of various types of construction material, such as bricks. Therefore, within the database of buildings of the IS, four series were defined.

\section{Results and Discussion}

"The unified methodology for designing and keeping a record of IS and PeS" was used for the determination of the key entities and attributes of the data model [9]. This makes it possible for the GIS to be used for planning and implementation of the PS. These entities are based on the methodology and specified types of objects and their characteristics. The entities were converted into a graphical form for the E-R diagram as shown in Figure 3. The figure depicts the actual entities, i.e., PeS, IS, their equipment, information on the planned construction of the IS, and supplies of materials, including type and quantity of materials needed for the implementation of the IS.
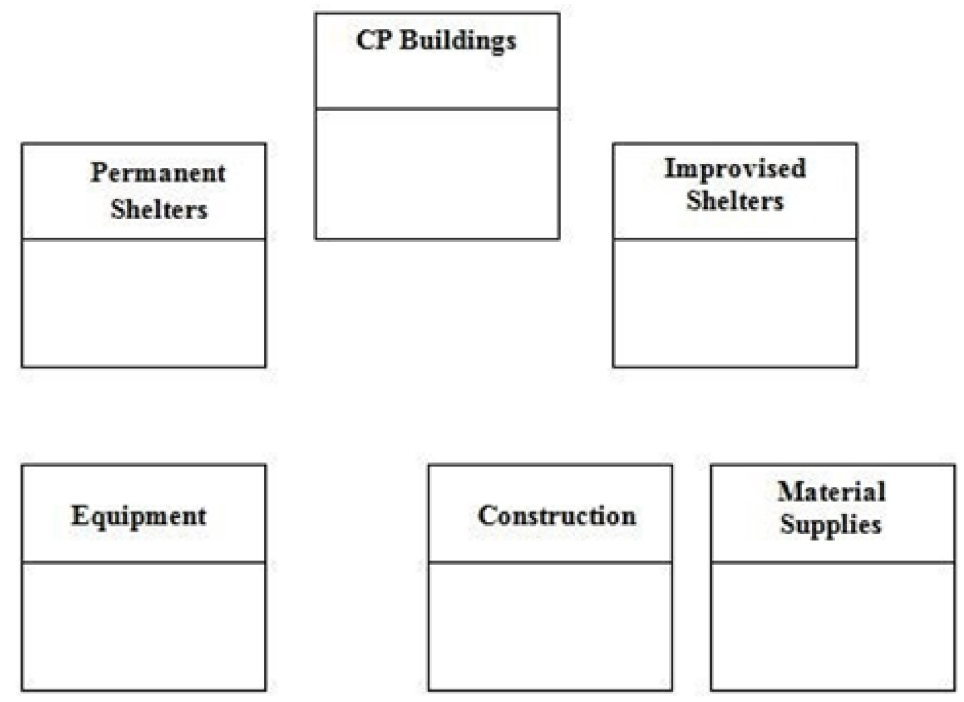

Figure 3. Defining entities.

The list of attributes for the given entities was obtained by analyzing the characteristics of the types of objects (Table 1). Together with the attribute determination, the abbreviations to be used in the model and its implementation are specified. Subsequently, the primary keys were determined (Figure 4).

Table 1. Defining attributes of the data model and their abbreviations.

\begin{tabular}{cc}
\hline Entity & Civil Protection Buildings \\
\hline Attribute & Registration Number of Shelter \\
\hline Entity & Permanent Shelter \\
\hline & Id PS; Registration number of shelter; Address \\
of shelter; Municipality/municipality with \\
extended power; Owner; Capacity (max./opt.); \\
Responsible person-contact; Peaceful use; \\
Commissioning Time (hours); Hours of \\
Operation (hours); FVE (yes/no); Position; Id \\
of Equipment; Id of Construction; Area (m); Id \\
of Material Delivery; Use for EE type; Public \\
Status PS; Nonpublic Status PS
\end{tabular}


Table 1. Cont.

\begin{tabular}{cc}
\hline Entity & Improvised Shelter \\
\hline Attribute & $\begin{array}{c}\text { Id PS; Registration number of shelter; Address } \\
\text { of shelter; Municipality/municipality with } \\
\text { extended power; Owner; Capacity (max./opt.); } \\
\text { Responsible person-contact; Peaceful use; } \\
\text { Commissioning Time (hours); Hours of } \\
\text { Operation (hours); FVE (yes/no); Position; Id } \\
\text { of Equipment; Id of Construction; Area (m); Id } \\
\text { of Material Delivery; Use for MU type; Public } \\
\text { Status PS; Nonpublic Status PS; Discarded PS }\end{array}$ \\
\hline Entity & $\begin{array}{c}\text { Equipment } \\
\text { Attribute }\end{array}$ \\
& $\begin{array}{c}\text { Id of Equipment; Phone; Local radio; Lighting; } \\
\text { Water supply; Sewerage; El. Energy; } \\
\text { Gas supply; Sanitary facilities } \\
\text { WC/washroom; Other }\end{array}$ \\
\hline Entity & Construction \\
\hline Attribute & $\begin{array}{c}\text { Id Construction; Shelter Location; Area of } \\
\left.\text { doors and windows (m }{ }^{2}\right) ; \text { Material of the } \\
\text { ceiling structure; The material of the perimeter } \\
\text { walls; Calculated building protection factor } \\
\text { after modifications }\end{array}$ \\
\hline Entity & Material Supplies \\
\hline & of material \\
\hline
\end{tabular}
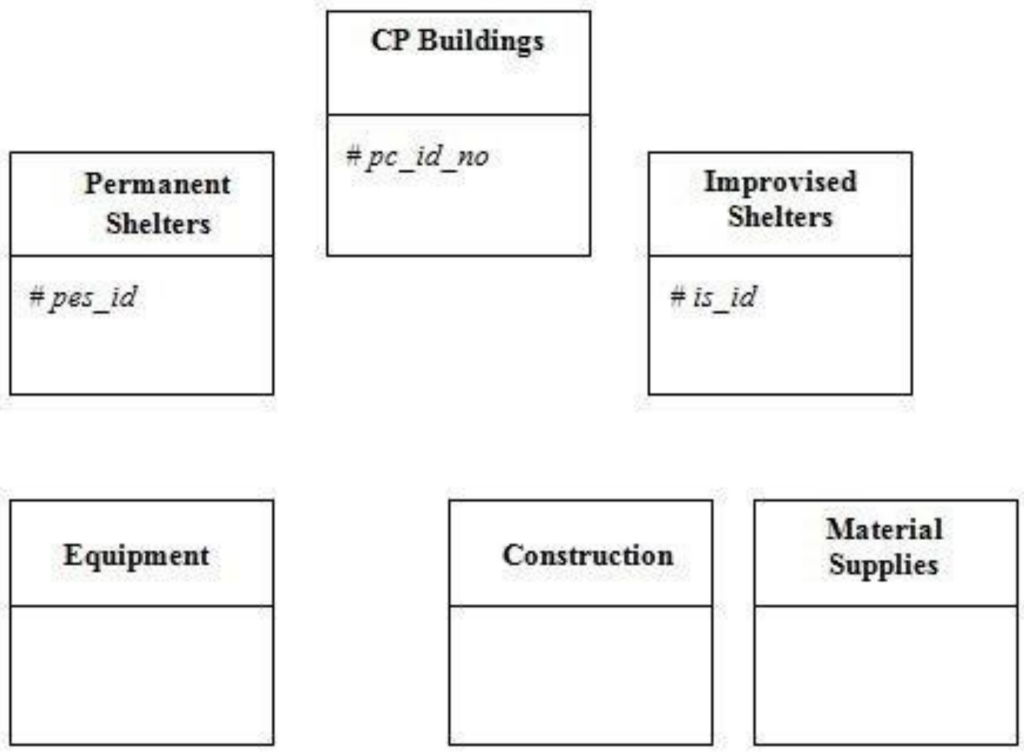

Figure 4. Defining primary keys.

The list of attributes for the given entities was obtained by analyzing the characteristics of the types of objects. Together with the attribute determination, the abbreviations to be used in the model and its implementation are specified. Subsequently, the primary keys were determined (Figure 3).

After defining entities and attributes the relations of individual entities are determined. As shown in the diagram, some entities become strong ( $\mathrm{PeS}$ and IS) and on the contrary, some become weak (equipment, construction and material supplies). In order to maintain 
clarity of graphic depiction, not all attributes were included. Additional attributes are based on the previously mentioned list of attributes. Defined relations are depicted in Figure 5.

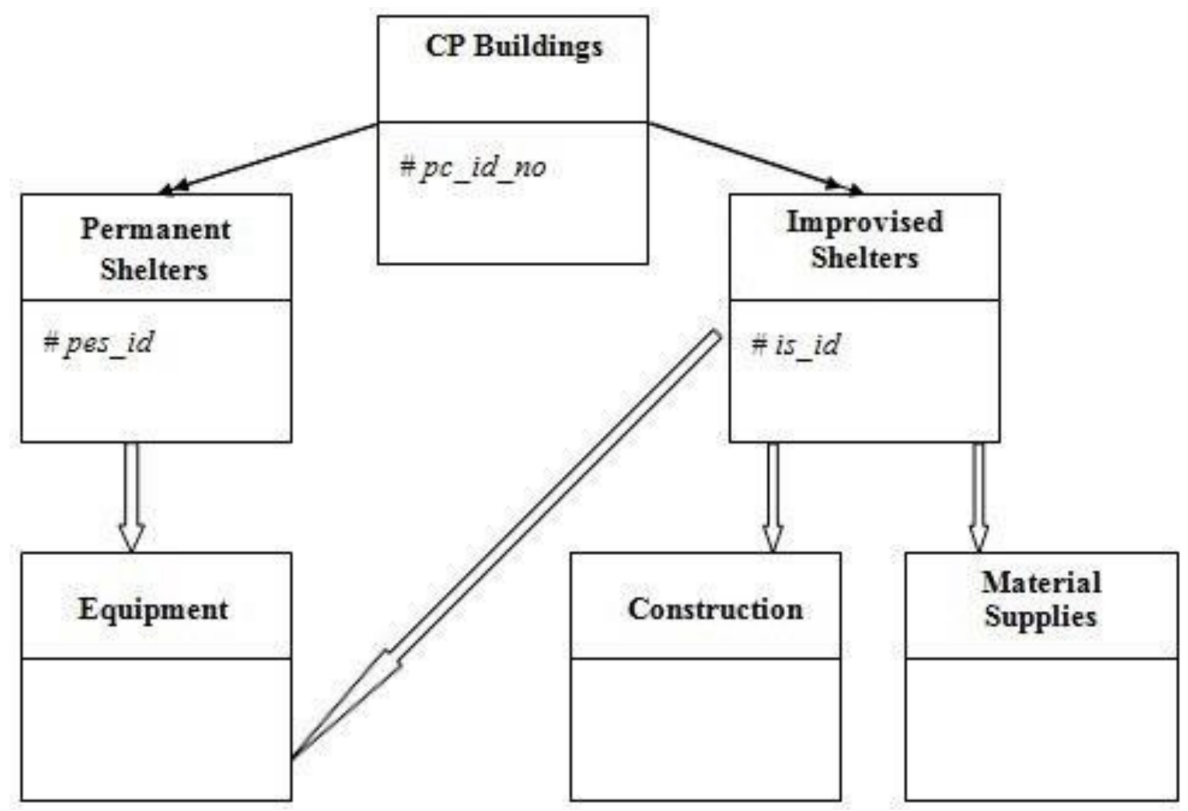

Figure 5. Relations of the data model.

Prior to the actual integration of sub-parts of the data model into the conceptual model, it is necessary to allocate and define the existing domains of individual attributes which constrain the values that the attributes may acquire. Domains are specified together with individual attributes of the said entities which are found in the list. Domains are specified in Table 2.

Table 2. Domains of attributes of the data model and their abbreviations.

\begin{tabular}{ccc}
\hline Entity & Attribute & Domain-Value \\
\hline \multirow{2}{*}{ Permanent Shelter } & Use for EE type & CBRN/Flood/Climate EE/other EE \\
& Public Status PS & Closed/Open \\
& Phone & Yes/No \\
& Local radio & Yes/No \\
& Lighting & Yes/No \\
& Water supply Sewerage & Yes/No \\
Equipment & El. Energy & Yes/No \\
& Gas supply & Yes/No \\
& Sanitary facilities & Yes/No \\
& WC/washroom & Yes/No \\
& FVE & Yes/No \\
\hline
\end{tabular}

In order to specify all necessary parameters, a simplified scheme of the logical data model was created on the basis of the previous design of the conceptual model. This scheme is depicted in Figure 6.

The actual data model was created by converting the logical data model into the target structures of the geodatabase and file systems. A board version was created for testing purposes.

An example of the output from the implemented data model in application QGIS 2.6.0 is shown in Figure 7. The figure depicts the main layers of the civil protection building, PeS and IS. 


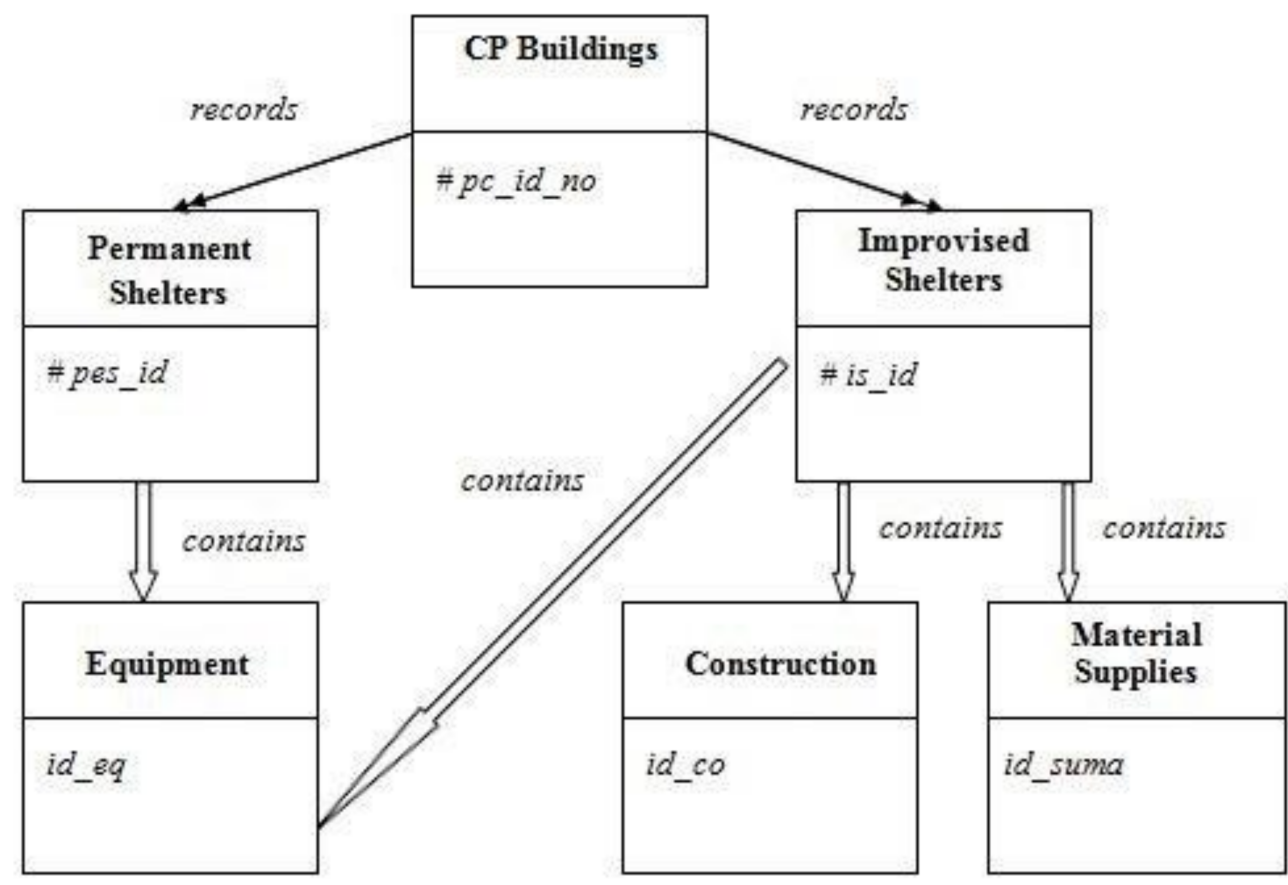

Figure 6. Simplified scheme of the logical data model.

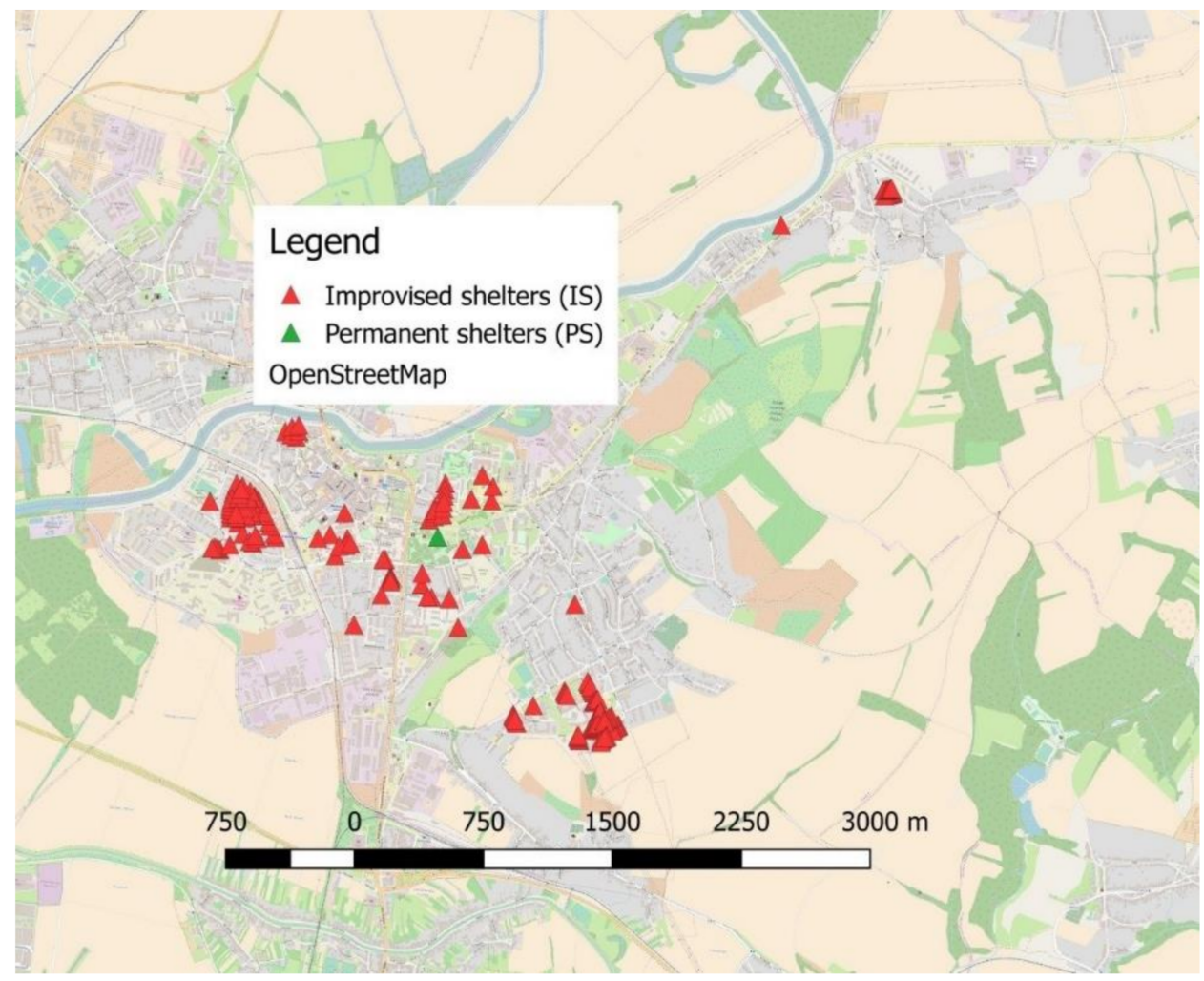

Figure 7. Objects of improvised and permanent shelters in the GIS in the town of Uherské Hradiště $[28,29]$.

By means of the QGIS, the implemented model was subsequently tested in laboratory conditions. The verification was performed by processing a randomly selected locality. The model functionality was tested by entering fictitious information. In addition, the possibility of using the model for spatial analyses associated with the PoS was tested [30]. Additionally, randomly selected analyses and tools such as buffer, intersect, difference, etc. were tested. Subsequently, random non-spatial analyses of attribute data were tested. Types of analyses are to be chosen with respect to the higher probability of using the GIS 
as an information support tool for the implementation of meaningful activities during planning and implementation of the PS. Due to a large number of possible analyses and tools in the GIS, it was possible to test all of them directly. In particular, analyses and tools with a higher probability of application in planning of the PoS and information support (InS) in this field were tested.

\subsection{Implementation of the Data Model for Planning and Management of the PoS Processes in Uherské Hradiště}

Implementation of the designed data model in the GIS as the InS tool for the PoS in the territory of Uherské Hradiště is the second stage of testing; it includes real-life testing and implementation into practice.

In order to verify the functionality of the data model, the first stage of implementation was performed. This stage included implementation of the existing PeS and the first part of the IS. The first part of the IS included objects owned by the town and objects in which the PeS used to be. The second stage of implementation included premises suitable for the IS which are not owned by the town. The total implementation of shelters to cover the needs of the PoS in Uherské Hradiště is a long-term issue that is to be addressed gradually. The gradual implementation of the second stage is caused by difficult data collection, as there is no possibility of ordering the population to cooperate in providing information about the IS in the buildings they own.

Therefore, the first stage included the identification of a single PeS in the territory of Uherské Hradiště, which is the shelter in the Hvězda cinema near the town center. Other selected premises for the IS included former PeS, which are no longer used for this purpose and do not have the necessary equipment anymore. Nevertheless, these premises still have sufficient protective parameters. Therefore, these premises have considerable potential for providing protection if appropriately modified into an IS. Moreover, construction adjustments that would reduce their protective potential are highly improbable.

The list of former PeS was obtained from the staff of the FRS in Uherské Hradiště, where they were registered in the past, and this information is also included in the data model in the form of a separate attribute.

Another aspect of defining the objects was based on an analysis of the list of buildings owned by the town. This list was obtained in cooperation with the Mayor's Office Department (Emergency Management Authority) in Uherské Hradiště. The list contained a large number of various buildings from which the premises suitable for construction of the IS were selected. These were, in particular, residential-type buildings with suitable premises for construction of the IS.

Upon obtaining the list of PeS and suitable premises for the IS, these were implemented into the GIS. The output from this implementation is depicted in Figure 8, which shows the map of the distribution of the PeS marked by a green triangle, while the IS are marked by a red triangle, and the potential premises for the IS are marked by a yellow rhombus. Figure 9 depicts an attribute table of implemented objects. A special methodology for designing and keeping a record of the PeS and IS was devised. This methodology has been completely processed for those objects for which the vast majority of data was acquired.

When collecting data, the series of residential buildings owned by the town were identified. These construction series were implemented into the data model by means of domains of a separate attribute. In particular, the following types of residential buildings were identified in the territory of Uherské Hradiště [31]:

- Type 1-residential buildings made of brick structure;

- $\quad$ Type 2-residential houses of the series OP 1.11;

- $\quad$ Type 3-residential houses of the series OP 1.31;

- $\quad$ Type 4-residential houses of the series G 32 . 


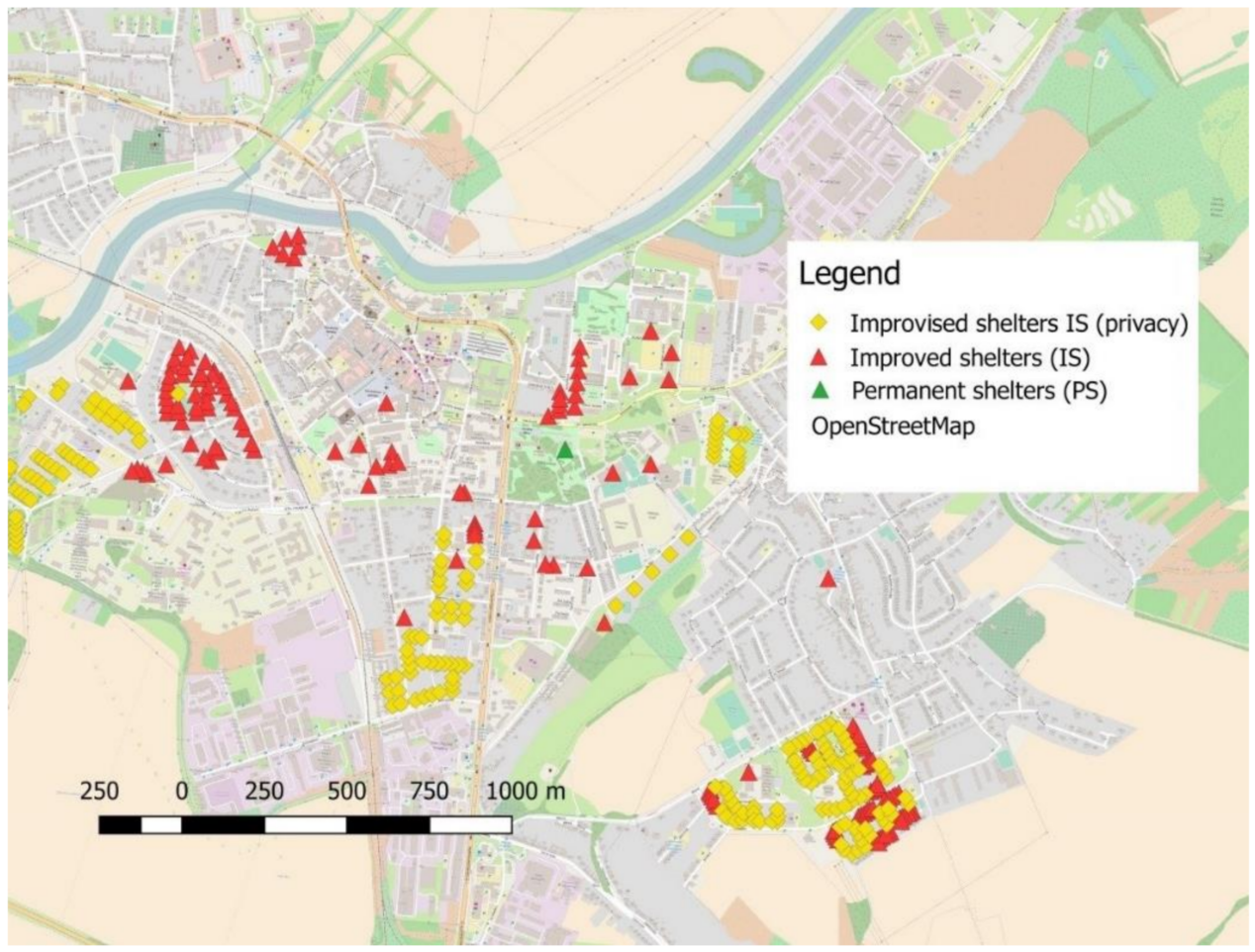

Figure 8. Objects owned by the town complemented by privately owned objects with the same design $[28,29]$.

\begin{tabular}{|c|c|c|c|c|c|c|c|}
\hline & ID & Reg. Number & Address & Village/ORP & Owner & Capacity & Responsible Pers. \\
\hline 0 & 1 & 10001 & B. Němcové 880 & Uherské Hradiątě & obec & NULL & - \\
\hline 1 & 2 & 10002 & B. Nèmcové 880 & Uherské Hradiątě & obec & NULL & - \\
\hline 2 & 3 & I0003 & B. Němcové 879 & Uherské Hradiątě & obec & NULL & - \\
\hline 3 & 4 & 10004 & B. Nèmcové 879 & Uherské Hradiątě & obec & MULL & - \\
\hline 4 & 5 & 10005 & Louky 517 & Uherské Hradiątě & obec & NULL & - \\
\hline 5 & 6 & 10006 & Louky 517 & Uherské Hradiątě & obec & NULL & - \\
\hline 6 & 7 & 10007 & Louky 518 & Uherské Hradiątě & obec & NULL & - \\
\hline 7 & 8 & 10008 & Louky 518 & Uherské Hradiątě & obec & NULL & - \\
\hline 8 & 9 & I0009 & Louky 519 & Uherské Hradiątě & obec & NULL & - \\
\hline 9 & 10 & I00 10 & Louky 519 & Uherské Hradiątě & obec & NULL & - \\
\hline 10 & 11 & I0011 & Louky 520 & Uherské Hradiątě & obec & NULL & - \\
\hline 11 & 12 & 10012 & Louky 520 & Uherské Hradiątě & obec & MULL & - \\
\hline 12 & 13 & I0013 & Louky 505 & Uherské Hradiątě & obec & NULL & - \\
\hline 13 & 14 & I0014 & Louky 505 & Uherské Hradiątě & obec & NULL & - \\
\hline 14 & 15 & I0015 & Jaroslava Staňka... & Uherské Hradiątě & obec & NULL & - \\
\hline 15 & 16 & 10016 & Jaroslava Staňka... & Uherské Hradiątě & obec & MULL & - \\
\hline 16 & 17 & I0017 & Jaroslava Staňka... & Uherské Hradiątě & obec & NULL & - \\
\hline 17 & 18 & 10018 & Jaroslava Stañka... & Uherské Hradiątě & obec & NULL & - \\
\hline 18 & 19 & 10019 & Jaroslava Staňka... & Uherské Hradiątě & obec & NULL & - \\
\hline 19 & 20 & 10020 & Jaroslava Staňka... & Uherské Hradiątě & obec & MULL & - \\
\hline 20 & 21 & I0021 & Jaroslava Staňka... & Uherské Hradiątě & obec & NULL & - \\
\hline
\end{tabular}

Figure 9. Attribute table of the IS layer of the data model implemented in the GIS in the town of Uherské Hradiště [28]. 
Based on the identified construction types of concrete flats owned by the town, objects of the same series in private ownership were identified. These blocks of flats are shown in Figure 8.

Objects owned by the town were complemented by privately owned objects with the same design as shown in Figure 8. Once the testing phase and data collection in the desktop version of the GIS were finished, the creation of a physical data model in the form of a web application followed. The web application was created in accordance with the requirements of the emergency management staff of municipalities. Figure 10 shows a demonstration of the default page of the application. The application is used for keeping a record and planning processes of improvised and permanent shelters. It is therefore possible to keep records of both PeS and IS. The left part of Figure 10 shows a section that serves for hiding and displaying the layers of PeS and IS. Both layers can therefore be hidden or displayed as required. Below the field for controlling the layers there is a field for data filtering. The filters are set separately for each layer. The data can be sorted (filtered) based on selected parameters. This makes it possible to filter the PeS layer according to the type of PeS, type of emergency event (EE) for which the PeS is to be used, or the PeS status (private or public). The IS layer can be sorted (filtered) according to the following attributes: type of the EE, shelter location (IS type), and protective coefficient of the building. The right field of the application displays in its upper part a map of the site of interest with the locations of PeS (red point) and IS (blue point). If users click on individual points (both PeS and IS), a pop-up window appears with a brief overview of the main attributes. These windows with attributes are depicted in Figure 10. Controlling the window with a mouse is relatively intuitive, or one can use controls at the top left of the window. In the lower right part, there is a table with an overview of attributes for both PeS and IS. In addition, the table is used for recording individual attributes, or inserting new buildings of PeS or IS. The main controls of the table are at the top. There is also a "switching" field for working with the PeS or IS (a), and a brief or complete display of attributes (b). From here, it is also possible to turn on the edit mode (c) and to export the database and the currently displayed map (d). The exact location of the individual controls is shown in Figure 8 (see letters in parentheses above). The lower part of the table is then used to display PeS and IS data. The data is displayed according to the conditions of set filters and set parameters of work with the database. At the top of the application, there is a bar with the title of the application and login/logout. The application can also be managed through this part (see Figure 10).

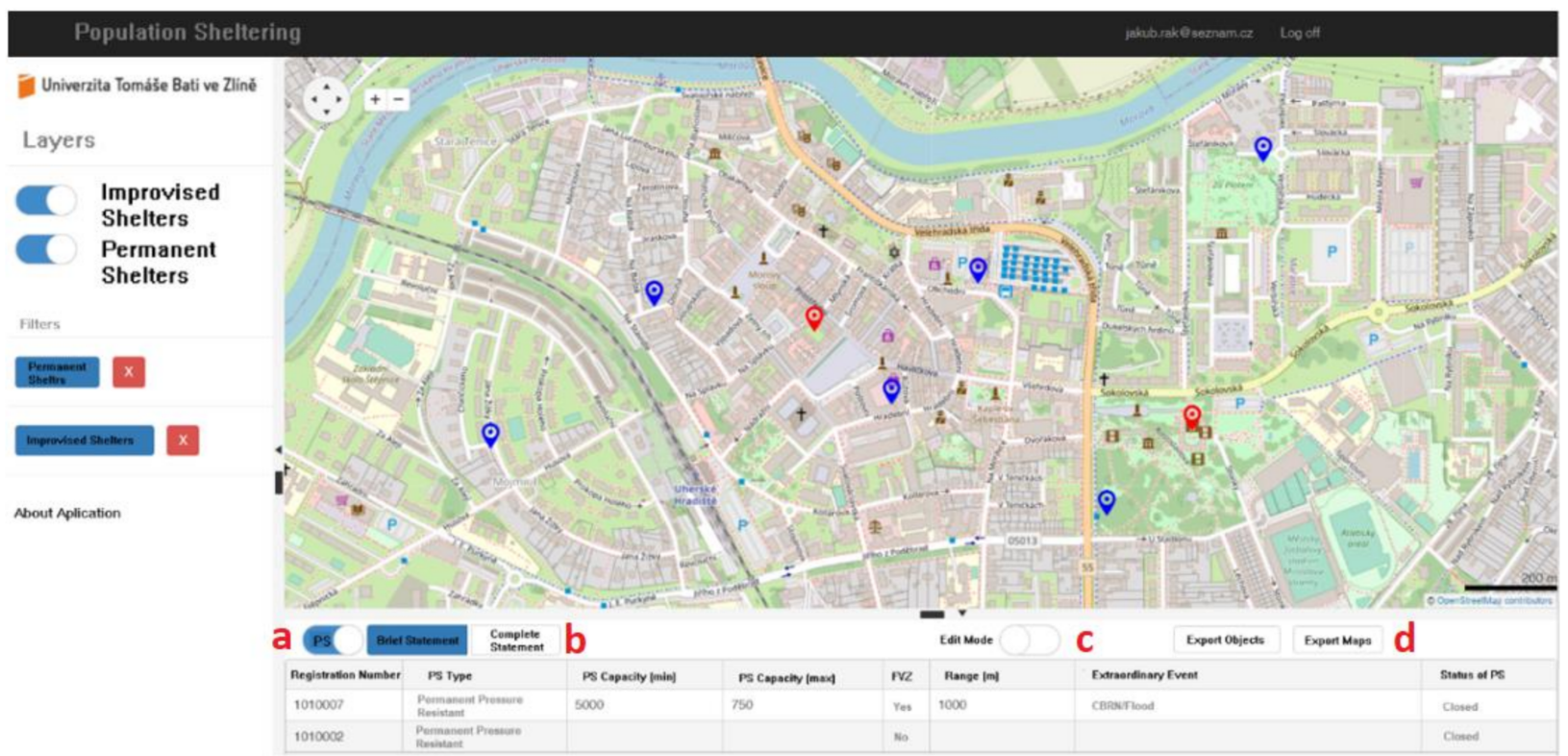

Figure 10. The default page of the web application of the final spatial data model [32]. 


\subsection{Applicability}

The obtained results from the data modelling will find their application in public administration and self-administration. The applicability is predominantly limited to the conditions of the Czech Republic (CR). However, the general principle of the proposed data model is applicable to other countries as well. In the Czech Republic, the field of population sheltering is legally regulated. Act No. 239/2000 and executive regulation No. 380/2002 [29] stipulate the obligation of municipalities or mayors to take steps in connection with the preparation of shelters for the population. The authorities concerned are therefore not only motivated but also obliged to implement the steps associated with keeping a record, planning and preparation of PeS and IS. The absence of a similar application on the Czech market makes its applicability relatively high. This assertion is also supported by the successful implementation of the application by the Emergency Management Department of the town of Uherské Hradiště, who actively use this application.

The application provides the benefits of implementing the methods of record keeping and planning of IS and PS, which is in accordance with the applicable legislation, and at the same time it respects long-term trends and knowledge in the field of population sheltering. Owing to the successful implementation of the application in the town of Uherské Hradiště, there are also other towns in the CR interested in the application. Considering the number of towns and villages in the CR, there is a relatively high potential for the practical use of research results. The research presented originated partly within the TACR research project. Therefore, publishing individual parts of the data model must be in accordance with the license agreement. For this reason, the source code of the application cannot be presented here, which, however, is the key aspect and main contribution of the research. Predominantly, the merit of the research is its design aspect, i.e., the conceptual data model.

\section{Discussion}

The resulting data model for the PoS confirms the possibility for the development of the InS using the information technologies (IT). The structure of the data model is based on "the unified methodology for designing and keeping a record of IS and PeS" [9]. This methodology is represented by a fundamental document for the PeS and IS and contains important data for the design and planning of PoS processes from the perspective of individual shelters (objects). In particular, the methodology was used by the data model in order to ascertain individual attributes of the relevant entities. The use of the methodology enables standardization of PoS processes and significantly contributes to the reduction in demands and costs for PoS preparation. The implementation of the methodology significantly contributes to increasing the sustainability of PoS processes. The methodology creates a comprehensive framework for a unified approach of crisis management personnel in individual municipalities compared to current support methods [15,16]. Similar attempts at standardization face limited possibilities to support PoS planning [18]. The methodology used here respects a comprehensive approach to PoS and contains a wider area of related attributes.

From this perspective, the article confirms the use of IT tools, namely the GIS and web technologies in the field of the PoS. Furthermore, for this reason the data model is designed as spatial. The structure and significance of individual attributes are based on detailed analysis and testing in laboratory conditions. In the course of this process, attributes were specified in such a way as to make the resulting data model as universal as possible. Versatility can be demonstrated by applicability in areas of different sizes. As part of the testing, the data model was applied to small and large cities. Practical testing was carried out in a medium-sized city. The versatility of use is also evidenced by the possibility of using the method of "standardization of objects for the IS" [20], which contributes to the facilitation of PoS processes.

It has been planned to use the designed model in practice since the very beginning of the research. For this reason, there was close cooperation with the emergency management staff of the town of Uherské Hradiště. This cooperation was essential mainly for defining 
the entities and attributes, as well as during testing the functionality and applicability of the data model and its implementation into the web application. This cooperation also contributed to the creation of a tool focused on InS applicable in solving real PoS processes.

From the perspective of the data model, defining the entities and attributes can be considered a critical part of the research. Despite a detailed systematic analysis, some attributes can be omitted, and the selection process may be further optimized. Therefore, creating the data model can be perceived as a "live process". The data model can be accessed any time and the attributes can be edited. It is also possible to delete, specify, or create a new attribute. This is a key feature which enables the data model to be optimized even during its use, e.g., when the security environment is changed, etc. In accordance with the main research hypothesis of the implementation of the PoS methodological framework into the proposed data model, it is appropriate to limit these processes to the maximum.

Other key feature of the data model is the possibility of its gradual implementation. The data model allows individual entities to be gradually implemented, and their attributes can be entered as needed. This will allw the staff of the emergency management to implement the data model gradually at their own pace. The scope of implementation of the data model also determines if the data model is only suitable for keeping a record, or whether it can be used as a full-featured tool for planning and implementing of the PoS. Utilizing this feature, the proposed model makes it possible to replace some current solutions [17] while creating the potential for wider use.

The process of selection of the premises for the IS in privately owned residential buildings has confirmed the hypothesis of the use of structural conformity in buildings with identical constructions. This assumption facilitates planning and preparation of the PoS in the town and demonstrates the importance of the data model as a tool for the InS in the process of the PoS. Although this hypothesis was verified, it is necessary to respect its limitations. These limitations include the size of the selected town, when there is a prerequisite of standardized blocks of flats, or standardized family houses.

Standardized family houses and other buildings are a topic for further research. Specification of the unified types of objects and their categories will allow the data model to be expanded, mainly due to reducing the workload of the security personnel. However, the data model allows full implementation even without the expansion of the standardized series. Another topic for further research is the application of the data model to other localities, especially those with fewer objects (i.e., small municipalities).

\section{Conclusions}

In conclusion, it is possible to say that the data model fully meets the given objectives of the research article, and it increases the security and enhances the development of the InS in the field of the PoS in the CR. In addition, the hypothesis: the data model must respect the methodological framework of the planning and implementation of the PoS, especially when used for the design and implementation of the IS, was also confirmed. The verification of the initial assumptions related to the data model was carried out under both laboratory and real-life conditions in the town of Uherské Hradiště [9]. Research proves the importance of IT in standardizing PoS processes. Furthermore, the results show an increase in the efficiency of process planning. An example is the possibility of applying the method "standardization of objects for the IS" (Section 2.2). Thanks to the application of this method, it is possible to facilitate the work associated with IS planning. Especially in larger cities, the benefit is high. The main benefit is the possibility of applying IS modification projects to several objects with the same construction properties (apartments). For example, in the object of type OP 1.11, it has a total of 271 occurrences in the investigated locality [20]. Such facilitation of work contributes to lower workload for civil protection personnel. Due to the time saved for PoS planning, employees can plan PoS to a greater extent even in previously neglected areas (IS planning). Another example is facilitating the presentation of the state of PoS to the public. Here, the spatial presentation is suitable for presenting data on the availability of free shelter capacities. 
Due to these benefits, the proposed data model contributes to an overall increase in the sustainability of PoS processes in the field of crisis management.

Author Contributions: Three authors participated in the research presented in the article. The main author J.R. defined the hypothesis and essential concepts and preformed the design of the data model and its implementation into the spatial SW. The second author P.T. created the web application and participated in testing and optimization of the data model. The last of the authors, P.S. worked with the methodology of the PoS and processed defining entities and attributes. In this field, he cooperated with the main author. All authors have read and agreed to the published version of the manuscript.

Funding: This work has been funded by the internal project of applied informatics in population

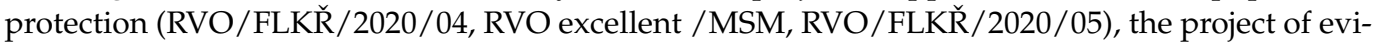
dence and evaluation of shelters (08/3/2018/GAMA), and the Department of Population Protection of Faculty of Logistics and Crisis Management at Tomas Bata University in Zlín.

Institutional Review Board Statement: Not applicable.

Informed Consent Statement: Not applicable.

Data Availability Statement: Not applicable.

Conflicts of Interest: The authors declare no conflict of interest. The founding sponsors had no role in the design of the study; in the collection, analyses, or interpretation of data; in the writing of the manuscript, and in the decision to publish the results.

\section{References}

1. Pacinda, S.; Pivovarnik, J. Kolektivni Ochrana Obyvatelstva; The Ministry of the Interior of the Czech Republic-General Directorate of the Fire and Rescue Service of the Czech Republic: Prague, Czech Republic, 2010; ISBN 978-80-86640-44-0.

2. Kratochvilova, D.; Folwarczny, L. Ochrana Obyvatelstva; Sdružení Požárního a Bezpečnostního Inženýrství: Ostrava, Czech Republic, 2013; ISBN 978-80-7385-134-7.

3. The Ministry of the Interior of the Czech Republic. Terminological Dictionary—Crisis Management and State Defence Planning. Available online: https:/ / www.mvcr.cz/clanek/terminologicky-slovnik-krizove-rizeni-a-planovani-obrany-statu.aspx (accessed on 29 September 2016).

4. Richter, R. Výkladový Slovnik Krizového Řizení; The Ministry of the Interior of the Czech Republic-General Directorate of the Fire and Rescue Service of the Czech Republic: Prague, Czech Republic, 2010; ISBN 978-80-86640-54-9.

5. Hladky, J. Krizové Řizení a Ochrana Obyvatelstva při Mimořádných Událostech. Ph.D. Thesis, Faculty of Education, Masaryk University, Brno, Czech Republic, 2010.

6. Kovarik, J.; Smetana, M. Základy Civilní Ochrany; Sdružení Požárního a Bezpečnostního Inženýrství: Ostrava, Czech Republic, 2006; ISBN 80-86634-85-X.

7. The Ministry of the Interior of the Czech Republic - General Directorate of the Fire and Rescue Service of the Czech Republic. Koncepce Ochrany Obyvatelstva do Roku 2020 s Výhledem do Roku 2030; Ministry of the Interior of Czech Republic: Prague, Czech Republic, 2001; ISBN 80-86056-47-3.

8. Rehak, D.; Pupikova, J. Ukrytí Obyvatelstva v České Republice; Sdružení Požárního a Bezpečnostního Inženýrství: Ostrava, Czech Republic, 2015; ISBN 978-80-7385-152-1.

9. Rak, J. Informační Podpora Ukrytí Obyvatelstva. Ph.D. Thesis, Tomas Bata University in Zlín, Zlín, Czech Republic, 2017.

10. Hylak, C.; Pivovarnik, J. Individuální a Kolektioní Ochrana Obyvatelstva ČR; The Ministry of the Interior of the Czech RepublicGeneral Directorate of the Fire and Rescue Service of the Czech Republic: Prague, Czech Republic, 2016; ISBN 978-80-87544-18-1.

11. Rehak, D.; Kratochvilova, D.; Kratochvilova, D., Jr.; Hegar, J. Metodika Stanovující Technické Požadavky pro Př́íravu Novostaveb k Provizornimu Ukrytí; Methodology Ev.no. CERO 6/2015; VŠB-TUO: Ostrava, Czech Republic, 2015.

12. Valenta, P. Informační Podpora Ochrany Obyvatelstva. Bachelor's Thesis, Tomas Bata University in Zlín, Zlín, Czech Republic, 2015.

13. Hoch, K. Informační Podpora Krizového Řizení. Bachelor's Thesis, Tomas Bata University in Zlín, Zlín, Czech Republic, 2007. Available online: http:/ /hdl.handle.net/10563/3584 (accessed on 9 September 2016).

14. System Online. Přístupy k Řízení Rizik Webových a Portálových Aplikací. Available online: https://www.systemonline.cz/itsecurity/pristupy-k-rizeni-rizik-webovych-a-portalovych-aplikaci.htm (accessed on 9 November 2017).

15. Reznak, P. Analýza Současného Stavu Zajištění Ochrany Obyvatelstva z Pohledu Malých a Středních Obcí v České Republice. Bachelor's Thesis, Tomas Bata University in Zlín, Zlín, Czech Republic, 2013. Available online: https://stag.utb.cz (accessed on 20 May 2018).

16. Maps Portal. Available online: http://gis.mesto-most.cz/krizoverizeni/index.html (accessed on 9 November 2017).

17. Datový Model pro Digitální Zpracování Sledovaných Jevů Územně Analytických Podkladů v GIS—Referenční Příručka Podrobná. Available online: http://www.c-budejovice.cz/cz/magistrat/odbory/.../DMG_\%C3\%9AAP_verze_4.p.f (accessed on 3 May 2017). 
18. Vokounova, L. Návrh Struktury Datového Modelu pro Správu Elektrických Distribučních sítí ZČE v GIS Analýzou Mezinárodniho Datového Modelu ArcFM; University of West Bohemia: Pilsen, Czech Republic, 2003.

19. Kaluza, J.; Kaluzova, L. Modelování dat v Informačních Systémech; Ekopress: Prague, Czech Republic, 2012; ISBN 978-80-86929-81-1.

20. The Czech Republic. Vyhláška č. 380/2002 Sb. k Přípravě a Provádění Úkolů Ochrany Obyvatelstva; Ministry of the Interior of Czech Republic: Prague, Czech Republic, 2006.

21. Schneider, M. Spatial Data Types: Conceptual Foundation for the Design and Implementation of Spatial Database Systems and GIS. Available online: https://www.cise.ufl.edu/ \{\}mschneid/Service/Tutorials/TutorialSDT.pdf (accessed on 10 October 2021).

22. Spatial Databases, Concept, Design and Management. Available online: http://www.geol-amu.org/notes/m14b-4-4.htm (accessed on 10 October 2021).

23. Sebeochrana Obyvatelstva Ukrytim; The Ministry of the Interior of the Czech Republic-General Directorate of the Fire and Rescue Service of the Czech Republic: Prague, Czech Republic, 2001.

24. Janecek, F.; Marusak, J.; Valasek, J. CO-6-1/č Příprava, Projektování a Výstavba Protiradiačních Úkrytů; The Ministry of National Defence: Prague, Czech Republic, 1978.

25. Hegar, J. Ochranný Součinitel Stavby; Hasičský Záchranný Sbor Moravskoslezského Kraje: Ostrava, Czech Republic, 2005; Available online: http:/ / hzsmsk.cz/sklad/prezentace/kraoo/17.pptk (accessed on 13 August 2010).

26. The Czech Republic. Nařizení Vlády 430/2006 sb. o Stanovení Geodetických Referenčních Systémů a Státních Mapových Děl Závazných na Území Státu a Zásadách Jejich Používání; Government of the Czech Republic: Prague, Czech Republic, 2006.

27. Rak, J.; Losek, V.; Svoboda, P.; Micka, J.; Balint, T. Využití typizace panelových domů pro potřeby návrhu databáze objektů pro ukrytí obyvatelstva v Uherském Hradišti. Sci. Popul. Prot. 2017, 2, 1-9.

28. Quantum GIS (QGIS), version 2.6.0. SW; QGIS Development Team: Zurich, Switzerland, 2014. Available online: http:/ / www.qgis. org (accessed on 17 November 2019).

29. OpenStreetMap. Available online: https://www.openstreetmap.org (accessed on 4 May 2018).

30. Rak, J.; Svoboda, P.; Vicar, D.; Micka, J.; Balint, T. Design of the civil protection data model for Smart Cities. In Applied Physics, System Science and Computers III, Proceedings of the 3rd International Conference on Applied Physics, System Science and Computers (APSAC2018), Dubrovnik, Croatia, 26-28 September 2018; Lecture Notes in Electrical Engineering; Springer: Cham, Switzerland, 2019; Volume 574, ISBN 978-303021506-4.

31. Rak, J.; Vicar, D.; Losek, V.; Balint, T.; Strohmandl, J.; Kozubikova, B. Design of a spatial database of standardized blocks of flats for the purpose of population sheltering in the town of Uherské Hradiště. WSEAS Trans. Environ. Dev. 2018, 14, 16-23.

32. Tomas Bata University in Zlin. Population Sheltering. Available online: www.uo.flkr.utb.cz (accessed on 12 November 2020). 